\title{
ON RAVENSTEIN'S EDITION OF BATTELL'S ADVENTURES IN ANGOLA AND LOANGO
}

\author{
JAN VANSINA \\ UNIVERSITY OF WISCONSIN-MADISON
}

Between 1590 and $c a .1610$ the English sailor Andrew Battell lived in Central Africa, first in Angola until 1606/07 and then in Loango. His reports about these lands are a priceless source for the otherwise poorly documented history of Angola between $c a$. 1590-1606, especially since his is the only known eyewitness account about the way of life of the notorious Jaga. $\mathrm{He}$ actually lived with one of their bands supposedly for at least twenty months (26-27). ${ }^{1}$ In addition his account is also one of the very earliest about Loango. Hence modern historians of Angola and Loango have relied extensively on him. They all, myself included, have used the text edition by E.G. Ravenstein of The Strange Adventures of Andrew Battell of Leigh (London, 1901) and did so without referring back to the original documents. These are, first Battell's information in Samuel Purchas' Purchas His Pilgrimage, or Relations of the World and the Religions observed in all Ages and Places discovered from the Creation unto the Present (London, 1613), and later, the more detailed "The Strange Adventures of Andrew Battell" in Samuel Purchas His Pilgrimes (London, 1625), also known as Hakluytus posthumus after its frontispiece. ${ }^{2}$ Given the absolute reliance of modern scholars on Ravenstein, it is worthwhile to evaluate its reliability compared to the original publications.

\footnotetext{
${ }^{1}$ All references in parentheses refer to pages in Ravenstein's edition and references to the two original editions in square brackets.

${ }^{2}$ Ravenstein used the re-edition of 1617 . I have only be able to use the re-edition of 1625 .
} 
Ravenstein's edition is not up to modern standards even though it nearly flawlessly renders the original main text . But he omits the pagination and the line numbers of the editions he used, he modernizes the spelling of the originals, and he does not state clearly that he added all the titles and everything else within square brackets. But these are minor blemishes compared to his other omissions and additions. He omits the headings at the top of each page which list a summary of the subjects discussed on that page. He omits nearly all the numerous marginal comments in the original and when he cites such a note, he only quotes a part of it, without indicating this in any way. He even occasionally splits paragraphs in two or three new ones. Most misleadingly however is his division of the text into arbitrary sections consisting of one or several paragraphs, for which he provides his own titles.

Finally he makes a mess of the long commentary in italics at the end of the original text of "The Strange Adventures," which was added by Purchas. Ravenstein mistakenly presents the first paragraph of this commentary as a marginal note (68-69), but then prints the following two paragraphs as if they were part of the main text, whereas they are but the continuation of Purchas' commentary. The main text therefore ends with "creatures, with robbery, exile, death." (68/11). The cumulative effect of all of the preceding is to completely disfigure the appearance of the original publications and the messages this sends to the reader. Moreover, Ravenstein printed the two sources in reverse chronological order; that is, he prints the 1625 "Adventures" first and then only the relevant passages in Pilgrimage 1613, In effect this veils any relevance this chronology might have.

Moreover, it stands to reason that after a century of use Ravenstein's annotation of the text are out of date. This alone would warrant a new text edition. In the same way, his introduction to the text edition has become quite inadequate today. Indeed it was already somewhat flawed when it was written. Thus in principle it would be desirable to produce a wholly new edition of this important text, Yet this is not likely to happen in any near future. Hence it is useful to provide faute de mieux an additional introduction for users of the Ravenstein edition.

\section{III}

For the following discussion-and as no manuscript of the original manuscripts has survived - I have used the printed texts of chapters 9 and 10 of the fourth edition of Pilgrimage (London, 1626), 765-72 and of The Strange Adventures...in Pilgrimes (London, 1625), 970-85. Let us first tackle the 
issue of authorship. Nearly all modern readers act as if Battell wrote the "Strange Adventures" all by himself, as if every statement in the text is in his very ipsissima verba, as if he had been an eyewitness to most of what he tells us, and as if the texts from 1613 represent a faithful record by Purchas of his conversations with Battell. ${ }^{3}$ How much better can a source get? Alas, the reality is different. Battell was only one of the sources of information for Pilgrimage and "Adventures" was not written by him. Hence none of the data in either book can be handled as if they were Battell's very own words. Rather the texts should be read as his oral reminiscences recorded by others.

To begin with, the two accounts were published twelve years apart. Purchas is the actual author of the text published in 1613 for which Battell was an informant whom he interviewed several times between $c a .1610$ and 1613. Hence Purchas set the agenda for their conversations, and Purchas retained only those reminiscences of Battell that he found to be useful. He also asked additional questions, noted Battell's replies, and again printed only those replies he found to be illuminating for his particular purposes.

The "Strange Adventures" of 1625 was written by a hitherto unknown anonymous author referred to only as "the transcriber." In a marginal note Purchas refers to a passage in this volume that deals with the poison ordeal and concerns an opinion by the narrator: “...But I think that...". Purchas comments: “... I think rather that this was the transcriber's conjecture. I remember no such scruple in his [Battell's] narrations to me...."4 Unfortunately, the word "transcriber"and the older verb "to transcribe" were and still are ambiguous. Among its meanings one finds (a) someone who copies a text and (b) someone who reproduces the matter of statements (a writing or a book) without regard to the wording. 5 The first meaning cannot be intended here and the second might or might not be so. One suspects that in the seventeenth century and even later "transcriber" also included someone who wrote down oral information. This transcriber obtained information from Battell at some time between 1613 and the latter's death, and obviously again recorded only what he (probably not a she) found relevant. These papers were then further edited by Purchas, most likely in 1622, and printed before the whole was seen by a corrector for a final check before publication. ${ }^{6}$

${ }^{3}$ Except for Paul E.H. Hair "Material on Africa (Other Than the Mediterranean and Red Sea lands) and on the Atlantic Islands in the Publications of Samuel Purchas, 16131626," HA 13(1986), 117-59.

4"Adventures," 61. The significance of this note escaped Ravenstein's attention, but Hair "Material," 129, 149n44, noticed this, It is also possible that the very title of the work ("The Strange Adventures," not "My Strange Adventures") hints that it was not written by Battell despite the pronouns "we" and "I "used in the text.

${ }^{5}$ Oxford English Dictionary, s.v. "transcribe."

${ }^{6}$ Purchas, Pilgrimes, preface not numbered, but 3-5 recto. Purchas tells us that half of the titles on each page are his own, and the others "such as pleased the corrector." 
Given the significance of the impact of the authors and of Battell on the text, a few words about them are in order. Samuel Purchas was born $c a$. 1577 at Thaxted, Essex and studied successively at Cambridge and Oxford. From 1607 to 1613 he was vicar at Eastwood, barely two miles from Leigh, where Battell settled after his return. Inspired by the example of the geographer Richard Hakluyt ( $c a$. 1552-1616), he sought out seafarers who had been in far away lands in order to use the information they had for a study of religion worldwide. He compiled all of this in his first book, entitled Purchas His Pilgrimage and subtitled or Relations of the World and the Religions Observed in All Ages of 1613, which he dedicated to Archbishop George Abbott of Canterbury. The Archbishop had him transferred to Saint Martin's Parish in Ludgate (London) during the same year and also appointed him as his own private chaplain. Moreover, Purchas became a protégé of John King, Lord Bishop of London. The Pilgrimage in the title refers allegorically to the notion of spiritual growth, and the book's contents were supposedly fertile ground for meditation. ${ }^{7}$

The work was a great success and brought renown to its author both in ecclesiastical circles and at court. It was republished in 1614, 1617, and 1626 in augmented editions, In later years and after the publication in 1619 of the long sermon Purchas, His Pilgrim. Microcosmus, or the Historie of Man, he set out to continue work on Hakluyt's endeavor and to extend his own Pilgrimage by publishing further accounts of travel. Now he let travelers as pilgrims speak for themselves and bear witness to the variety of human destiny. Thanks to his patrons in the Anglican church and at court he was able to spend four summers (1621-24) at a retreat in Chelsea in order to compose this work. From there he sent it, probably section after section, to the printer. ${ }^{8}$ If so, the volume on Africa was edited in 1622. It all culminated in 1625 with the publication of the massive four volumes of Purchas his Pilgrimes. Purchas died the following year in London.

Nothing is known of the anonymous transcriber-not even if there was only one. He composed "The Strange Adventures" after 1613 in or near Leigh. ${ }^{9}$ Because Purchas actively encouraged the publication of travels, as

${ }^{7}$ On Purchas as a writer and editor see James P. Helfers, “The Explorer or the Pilgrim? Modern Critical Opinion and the Editorial Methods of Richard Hakluyt and Samuel Purchas," Studies in Philology 94(1997), 174-75; P.E. H. Hair, "Material on Africa (other than the Mediterranean and Red Sea Lands) and on the Atlantic Islands in the Publications of Samuel Purchas, 1613-1626," HA 13(1986), 117-59.

${ }^{8}$ Purchas, Pilgrimes, I preface, f. 3/p. 5. If the sections of the manuscript were sent to the printer in the order in which they were composed and at the end of each summer, then the Battell text was probably finalized in 1621 or 1622.

${ }^{9}$ Could he have been the vicar who succeeded Purchas in Eastwood? Also the strikingly different organisation of chapters 5-7 suggests that a second transcriber could well have been involved. 
we know from the example of Jobson, Battell's transcriber/s may well have been chosen (and paid?) by him. ${ }^{10}$ This is far more likely than that a frustrated Battell, unable to tackle such a lengthy work by himself, hired such a person. In any case the transcriber was not working on his own behalf-otherwise he would not have remained anonymous.

Everything we know about Andrew Battell himself stems either from Purchas or from what is told in Adventures. This mentions only the single date-1589-when he left England on a privateer, presumably as a young man. Captured in Brazil, he was sent to Angola, where he stayed until the spring of 1607, when he fled to Loango. ${ }^{11}$ He returned from Loango to Leigh at an unknown date before 1613, probably in 1610/11. We cannot be more precise because "Adventures" lacks any account of his return to England. ${ }^{12}$ By his own (unreliable!) estimate of the time he spent there, he probably left Loango early in 1610.I surmise that he traveled on a Dutch ship to Holland, and then from there to the Thames estuary. ${ }^{13}$ No doubt his arrival at Leigh provoked a sensation after a twenty-year absence from the neighborhood, and thus drew the attention of Purchas at nearby Eastwood. Purchas befriended Battell and interviewed him several times between 1610 and 1613, when Purchas left Eastwood. Battell continued to reside at Leigh, probably until his death some years later, although there is no record of his

${ }^{10}$ Hair, "Materials" 121.

${ }^{11} \mathrm{He}$ left the city temporarily after he heard that the governor succeeding Manuel Cerveira de Pereira was expected , and when it became known (39) that "the new governor would came not that year," he went into hiding for six months (his estimate) before fleeing Angola. Simão da Cunha was offered the governorship of Angola but he refused the post before 14 February 1606, whereupon Manuel Pereira Forjaz expressed an interest. He received notice of his appointment on 2 August 1606 (António Brasio, Monumenta Missionaria Africana. Africa Ocidental, 5:166-67, 171, 214, 214n., 246, 264-79, 289 , 294, 313), but his departure was delayed, probably because of the Butaca affair. He actually left Lisbon only shortly before 31 May 1607 and arrived in Angola before October 1607. "The new governor" probably refers to him, and his retention in Lisbon might have been known in Angola by October 1606 at the earliest. Hence Battell probably fled Angola in the spring of 1607. This date tallies well with Purchas' estimate that Battell spent eighteen years in Angola, at least if Purchas did not count Loango as Angola. See Hair, "Material," 129.

${ }^{12}$ Most travel accounts omit any detailed mention of their return voyages. Is this omission here due to a cut by Purchas, a decision of the transcriber to omit it, or to discretion on the part of Battell himself? Is it even possible that Battell absconded with the funds of the shop he managed, like many agents in Angola would do in later years?

${ }^{13}$ By his own reckoning: at the earliest 2.5 years $(77-$ stated before 1613$)$ from late 1606 or early $1607=1609$; at the latest: 3 years $(41-$ stated after 1613$)$ is 1610 , but as the discrepancy in his statements shows, his reckoning is unreliable. Note his whole stay $1589 /(1590)$ to $1609 / 10$ lasted 20/21 years . An arrival in Leigh late in 1610 or even early 1611 is the most likely. 
burial there. He died before 1625 since a marginal note (55) by Purchas in "Adventures" mentions "these papers came to my hand since his death."

About Battell's stay in Africa we learn from "Adventures" that he was employed in Angola as a sailor, a soldier promoted to sergeant in 1602/03, and a trading agent for the governors Jõao Furtado de Mendonça and Manuel Cerveira Pereira. He left Angola in the spring of 1607. The manuscript is very discreet about his activities and his employment in Loango. Still we learn $(41,80)$ that he was "well beloved of the king, because I killed him deer and fowls with my musket." We further hear that he stayed for nine months (82) or a year (57) at Mayumba, probably as the manager of a shop there. ${ }^{14}$ Although we don't known for whom he worked there, that person may have been Portuguese. Possible indications of this are the following: when Battell sent an African envoy from Mayumba to contact the ruler at Sette, the latter requested Portuguese traders from the south, and when Battell sold a load (58) of elephant's tail hair that he had bought in Tsogho country (now southern Gabon), it was to Portuguese traders in return for slaves and his expenses. ${ }^{15}$

Since Battell needed a transcriber to compose "Adventures," he was either illiterate, or more likely barely literate, as was the case with most English sailors of the time and we encounter telltale signs that his "transcriber" wrote down what Battell told him orally. Yet in a marginal note to that book Purchas (20) writes that " $[t]$ he Gagas, a most warlike people. He in discourse with me called them Iagges, and their chief the great Iagge. I think he writ them Gagas for Giagas by false spelling." This implies that Battell could write.Yet the pronoun "he" may not refer to Battell at all, but to his transcriber, because Purchas could be careless with his pronouns in his marginal notes. Thus in yet another one of these (55) he writes: "He said, their height was like a man's, but their bigness twice as great. I saw the negro boy." In this passage both the "he"and the "I" must refer to Battell and Purchas went without any warning from an indirect to a direct quote in the same sentence. ${ }^{16}$

Could a passage in "Adventures" in which two nearly identical accounts about the poison ordeal in Loango seem to follow one another at the end of

${ }^{14}$ Pieter van den Broecke in K. Ratelband, ed., Reizen naar West Afrika van Pieter Van den Broecke, 1605-1614 ('s Gravenhage, 1850), 43, 57. In January 1610 there was a local factory there managed by Lowies Mendis (Luis Mendes). In 1612 its manager was Francisco Delmede Navero. Battell had probably worked for this factory.

${ }^{15}$ Elephant's hair was in great demand in Angola and Kongo. There are four further mentions of Battell in Loango, namely a "I was once there [ at the court]" (47) twice "I have asked X" 49,59) and one in a marginal note by Purchas: "I saw the Negro boy" (55).

${ }^{16}$ As Ravenstein (xi) wrongly inferred. So did Hair, "Material," 148n43. 
chapter 6 (59-62) be an indication that Battell wrote the first of these, which then served as a draft for the transcriber? I think not, because the repetition was apparently intentional, since the second account speaks of " $\ldots$ the foresaid root Imbonda," which is referred to in the first one as Imbondo. Actually, the appearance of two successive accounts is an illusion created by Ravenstein's procedures. First he separated them by placing a long note of Purchas that was originally in the margin between them, and then he added a separate section head before the second paragraph. In the 1625 book the whole appears as a integral account in two paragraphs, and there are two paragraphs because this ordeal was resorted to in two different sets of circumstances. ${ }^{17}$

\section{IV}

Any analysis of Battell's data in "Adventures" must separate the marginal notes of Purchas from the main text because the information in the latter stems from up to a decade earlier. Hence I examine the notes separately after discussing the main text. The latter is divided in seven parts or chapters, with titles provided most likely by the transcriber. In the original, no chapter is subdivided and all titled subdivisions in Ravenstein must be disregarded. We don't know whether all the marginal notes in "Adventures" stem from Purchas or whether the transcriber provided some. The single starred marginal note, however was certainly inserted by Purchas. Nor do we know whether the transcriber or Purchas came up with a title for the whole work.

The most striking feature of the report is the contrast between the four first chapters and the remainder. The first chapters are arranged fairly rigidly in the chronological order dictated by the adventures of the protagonist, Battell,who figures prominently in them. The dominant literary device is capture-captivity-evasion/expulsion, and the segmentation between chapters always occurs after an evasion/expulsion: chapter 1 deals with the period before he arrived in Angola, chapter 2 with his stay there until he was expelled and met the Jaga, chapter 3 with his life among the Jaga until his departure, and chapter 4 with his subsequent experiences in Angola until his escape.

In sharp contrast, the last three chapters are descriptive rather than narrative. They ignore both chronology and Battell's own activities. Indeed the protagonist becomes nearly invisible here. Perhaps Battell's detailed memories about these years of the recent past required too many explanations of little interest to his audiences to make sense. Perhaps life during this period

${ }^{17}$ This instance shows how misleading Ravenstein's edition can actually be. 
was so routine that he did not remember anything special, but that is not likely, for his move to Mayumba and then his trips to Gabon certainly broke the routine. Or perhaps Battell died before the transcriber had finished with the part about Loango. Whatever the reason, the transcriber deliberately cut out most of the information about Battell's own situation. Thus he omitted a description of Battell's house in Loango and the concomitant story (80) about the theft of some of his belongings printed in 1613. From that passage he only kept a single clause which he then moved inside the last sentence (41) to chapter 4. Chapters 5 and 6 are rather static geographic descriptions, dealing with Loango city and its royal court and, in imitation of Antonio Pigafetta's book, details on the provinces of Loango. ${ }^{18}$ The concluding chapter is a miscellany. It might have started life as a contribution to natural history, most likely inspired again by Pigafetta. But during the redaction that framework broke down and the chapter came to include data about animals outside Loango, about fishing along the Loango coast, and even about the imposition of vassality in Angola, before petering out with a comment on bees. Either the transcriber was in a hurry to meet a deadline or he just was not very competent. ${ }^{19}$

The contrast between the styles of the first and second part of the 1625 text is so great that one is tempted to suppose that they were composed by two different transcribers - a supposition that cannot be checked for want of a manuscript. But on the other hand descriptive passages also occur in the first part of the work. In chapter 2 the narrative part is followed by a threeparagraph-long description (17) of Benguela, a hitherto unknown land, while a series of descriptive paragraphs without much internal coherence (28-35) follows the narrative portion(19-28) of the Jaga chapter. So perhaps there was only a single transcriber after all. But why then did he change his approach? We might never know.

Ravenstein reprinted only three of the many marginal notes provided by Purchas for "Adventures," and then only incompletely. One concerns the spelling of Gaga (19), the second speculates about the great ape, which is not described in the text (55), while the last relates to the poison ordeal in which Purchas disputes (60-61) the main text by citing what Battell told him before 1613. Ravenstein also reprints the final portion in italics, which con-

${ }^{18}$ This chapter is clearly inspired by the topics in the notes on natural history in Pigafetta Lopes Filippo Pigafetta and Duarte Lopes, Relazione del Reame di Congo e delle circonvicine contrade (Rome, 159). We cite the well-annotated French translation by Willy Bal, Description du Congo (Louvain, 1965). For animals: see ibid., 51-63 (Book 1, chapter 8), plants 76-78 (Book 2, chapter 1).

${ }^{19}$ If this is correct, the text of "Adventures"was completed after Battell's death, which then occurred in 1624 at the latest. 
cerns the baobab and palm trees, followed by a crocodile story (68-70) as if it belonged to the text of the transcriber, whereas it was written by Purchas himself. Most of the marginal notes merely refer to the topic discussed in the paragraph next to the note and perhaps many of them were provided by the transcriber and not by Purchas. This does not really matter since Purchas edited the work and would have deleted or altered any notes of which he did not approve. Thus all the notes represent his reactions to, and opinions about, the text. When one remembers how well-connected Purchas was, it is evident that these marginal notes, as well as the end table (index) are especially relevant for scholars who want to evaluate the impact of this book on the image of Africa held in leading English intellectual and political circles of the time. What can be more blatant for instance than the entry for "Jaga" in the Table:

Gagas or Giagas discovered [974]. The Gagas are the greatest Maneaters in the world ibid. Their Wars overrunning Countries, their rites and manners of life etc. [975, 976, 977]. The Great Gaga [975]. The Gagas destroy all their children, burying them quicke [977]. The lagges or Giagas are the most dreadful and devilish people in the world [1025].

"Adventures" was created after 1613, but the transcriber (and Battell if he could read) probably had access to Battell's interviews with Purchas before 1613 as printed in Pilgrimage, and there are correspondences between the texts of Purchas and those of the translator. Nearly all of these, however, concern the Jaga or Loango and "Adventures" copies none of them literally. The correspondences by subject of Pilgrimage with "Adventures" are the following:

chapter 3: 5 items in all: tusks $(72,24-25)$; infanticide $(84-85,32-33)$; human sacrifices (86-87, 33-34); burial customs (86-87, 34-35); and the passage on Jaga origins $(83-85,19-20)$.

chapter 5: 2 items: albinos $(81,48)$; Nkisi or fetishes $(72-73,80-81,48$ 49).

chapter 6: 4 items: great apes ( 54-55 and marginal note there not in Pilgrimage); hunting dogs (74, 55-56), Maramba (82-83, 56-58), poison ordeal (80-81, 59-62). "Adventures" includes only one out of six topics about Angola in Pilgrimage and that occurs in the Jaga section of "Adventures." The latter includes all the Jaga items found in Pilgrimage, as well as those concerning Loango, with the exception of two entire paragraphs (77-79) 
about funeral rites and religious prohibitions in the middle of the text. The fact that the transcriber excluded these data suggests that they had not been obtained from Battell, even though Battell is cited as the single source for the whole part about Loango in Pilgrimage. "Adventures"is far more extensive than Pilgrimage on Angola (chapters 2 and 4) and included little from Pilgrimage, but it is striking to see the emphasis on Jaga (it repeats everything mentioned in Pilgrimage in the descriptive part of chapter 3 just as it does for five of the seven original paragraphs on Loango).

The most striking feature of all this is the lack of precise correspondence between passages from both books. It is revealing that the single instance of almost word-for-word copying that occurs between them is the crocodile story $(70,75)$, both versions of which were actually written by Purchas. Otherwise no passage in "Adventures" is copied from Pilgrimage, nor are most passages a mere paraphrase of Pilgrimage. Usually some information is added, less often omitted, and there are occasional discrepancies. The passages in "Adventures" tend to be somewhat longer-as one would expect. To give an example about the topic of burial. Pilgrimage (73-74) labels it an Angolan custom, while "Adventures" (34-35) specifies that this is a Jaga as well as an Angolan custom, and it is placed at the end of the Jaga section. The common points between the two passages are that the deceased is washed and well dressed, a burial vault is made, the corpse is buried in a seated position, and people are buried with most of their goods. Goats are killed and wine poured in their memory. All the rest is different. Pilgrimage is much shorter but specifies painting, new clothes, and beads, while "Adventures" speaks of an "embroidered head," anointing, two wives buried with the deceased, three-day memorials every month as long as "any of their kindred" be alive and consisting of songs and sacrifices, the unhappiness of people without kindred and the kindness of people to each other when healthy, but their avoidance of anyone who was ill.

Not all the additions or changes in "Adventures" are innocent additional remembrances of Battell. Look, for instance, at a small example about dogs. Pilgrimage (74) mentions prick-eared curs of average bigness, who are used to hunt with and who wear clappers because they do not bark. He saw a mastiff sold for three slaves. "Adventures" confirms this but is more specific about whose dogs he is describing, about what and how they hunt, and about the esteem in which great dogs are held because they bark, but now Battell saw a mastiff sold for thirty pounds. The change is probably due to the transcriber since the readers were more familiar with pounds than with slaves. But the change may also be a euphemism to avoid mentioning slaves.

The following case is more complex: "He saith they are called Iagges by the Portugals, by themselves Imbangolas (which name argues them to be of 
the Imbij and the Galae before mentioned) and come from Sierra Liona" (Pilgrimage 83-84). Compare this with "[w]hen they told us that they were the Gagas or Gindes, that came from Sierra de Lion and passed through the city of Congo and so traveled eastwards of the great city of Angola, which is called Dongo" ("Adventures" 19-20). The first passage, is quite short if we disregard the interpolation by Purchas. The second one drops the mention of Imbangala, but adds the one of Ginde and also informs us about the supposed route of travel through Kongo and Angola. While Ginde might well be a genuine further remembrance, the omission of Imbangala is certainly due to the transcriber and may not be innocent because it makes it easier for readers to identify these people with the Jaga of Kongo. This also explains the addition of the route the Imbangala traveled, a statement probably elicited from Battell, who repeated hearsay or even speculation he had heard in Angola. Since they did not come from that direction the Imbangala could not have given him this information. Moreover it is hard to believe that Battell forgot to tell this detail to Purchas before 1613, and even less that Purchas did not deem it fitting to include this information if he had been aware of it.

One concludes from the whole situation that the transcriber did not copy anything from Pilgrimage, and that the relationship between the pairs of texts in both works results from two successive recordings of the same set of oral memories. The transcriber interviewed Battell from scratch. He may well have refreshed the latter's memory by reminding him of some points in the testimony given before 1613 to Purchas, but he obviously did not systematically query Battell point by point. Hence the resulting discrepancies and the complementarity between both works, which are especially valuable because they are an excellent indicator of the overall reliability of Battell's powers of recall.

\section{VI}

Although most scholars have made little distinction between Pilgrimage and "Adventures," it is crucial to remember that Purchas is the author of the first book and merely an editor of the second. His friend Battell was used as an authority for certain passages in Pilgrimage (72-87). Purchas focused his interviews on the information he wanted and ruthlessly ignored the rest. He inserted the data he retained at appropriate places in chapters 9 and 10, which concern central Africa. Chapter 9 consists of three sections headed respectively Of Angola [ 765-66], Of Congo [766-68], and Of their Heathenish Rites: also of their Strange Trees and of the Ile of Loanda [768]. Chapter 10 contains the sections Of Loango [770-72 ], Of the Anzigues [772] a section in which nothing is attributed to Battell, Of the Giacchi or 
Iagges [772-73], and Of the Lakes and Rivers in these parts of Africa [77374]. The Iagges section lumps both the Kongo Jaga and the Angolan Imbanga la into a single unit and places it after the Anzigue under the influence of Pigafetta. ${ }^{20}$ In Pilgrimage [766] (75) Purchas tells about the importance of horsetails, most of which relates to the Pampas of Argentina. The only connection with Congo/Angola is "[h]orse-tails are great jewels and two slaves will be given for one tail"which probably stems from Brazilian information and is perhaps not from Battell at all.

As to the other passages, four of the six of those that concern Angola deal with religious subjects (idols, trial by ordeal, burial, moon worship). The other two concern the location and government of Kisama and dogs that cannot bark. The two passages about Congo deal with crocodiles and various trees. The eight passages about Loango all relate to religious matters (offerings, funeral rites, prohibitions, poison ordeal, three about "idols" and one about the endowment of albinos with supernatural powers). Finally, the Jaga topics discuss their origins, infanticide, and human sacrifice/cannibalism. Thus, in keeping with the goal of his work, Purchas retained mostly religious topics, but could not refrain from adding some other information, ranging from the location of Quisama to the uses of exotic trees, zebras, apes, and crocodiles, probably inspired by similar data he found in Pigafetta.

\section{VII}

The main contributions of Purchas to "Adventures" are his marginal comments and of some (most?) of the notes. Their main intent is to draw the attention of the readers on certain points and thus to mold their image of Battell's Africa. Any study of that topic must use these as primary data because they directly document the reaction of Purchas to the text and its significance as he saw it as illustrated by the entry cited from the Table of "Adventures." These notes also guided his readers in their appreciation of the text. Attention to the notes further shows that Purchas deleted at least one passage: a marginal note reads "[s]uch differences between Wasps and Bees" without any connection either with the paragraphs it faces, which deals with palmwine, or with any other place in the text [976], (36). Obviously the paragraph on that topic was deleted by Purchas although he still allowed a passage on bees to stand (68-69). The same anomaly also proves that some marginal notes at least are due to the transcriber.

${ }^{20}$ Bal, Description, 70 ( Book 1, chapter 12). Note the connection made there between Jaga and Agag. 
Apart from the marginal notes, there are no obvious signs that Purchas intervened much as editor in the text of "Adventures." Ravenstein thinks that he transposed part of the manuscript by placing (7-9) the trading trips Battell made for governor João Furtado de Mendonça far too early in the manuscript, and that he abridged portions of the manuscript, such as for instance the trading trip to Kongo and Mbata but Ravenstein did not realize that that there had been a transcriber (xii, xiii). Indeed, wherever trading trips appear in the manuscript, they seem to have been abridged, and the transcriber is perhaps more responsible than Purchas. But Battell's memory must be blamed for any chronological transpositions.

The transcriber of "Adventures" left no indication about his criteria regarding the organisation of the text, the exclusion of information, his own additions, and decisions about spelling. ${ }^{21} \mathrm{We}$ only know by chance that he excluded some of Battell's reminiscences because he left out the description of Battell's house in Loango from Pilgrimage (80). We suspect that he cut out most details about the trading trips mentioned, as well as most details of the narrative about the experiences of Battell in Loango. Since these were Battell's most recent memories it is likely that he remembered them in detail but the text does not record them.

The transcriber is also responsible for the spelling of most or all foreign words. Thus he transmogrified Portuguese names, but not all other Portuguese words, into Spanish - e.g. João Furtado de Mendonça becomes (7) Don John Hurtado de Mendoça. Purchas spelled Sierra Leone as Sierra Liona $(84,85)$ but the translator has Serra Leôa, Serra de Lion, and Sierra de Lion $(19,33)$. Moreover his spelling of foreign words and expressions is wholly inconsistent. Thus we have Cuanza, Quanxa, Gonsa, and Gunsa, all designating the Cuanza River and the notorious Jaga are usually rendered as Gaga but sometimes as Giaga (20) or Iagge (as Purchas spelled it). Even Luanda is St Paul or San Paulo, and Longo occurs for Loango . The practice for transcribing Bantu words is especially rudimentary and variable. For instance it is striking that final vowels and even syllables are unstable (e.g. Elamba/Elambe, Benguelle/Benguela, or Calandola/Calando). And it is the transcriber rather than Purchas who is responsible for Miller's "numerous additions made by an editor in Europe." 22

It follows from all of this that the overall impression Battell's adventures left on the seventeenth-century reader was shaped in the first place by the transcriber and by Purchas and corresponded to the expectations, prejudices, and predilections of these authors. Battell had no input at all into this process and anyway he died before the publication of his "Adventures,"

${ }^{21}$ Unlike Purchas; see Hair "Material," 120-22.

22Joseph Miller, "Requiem for the 'Jaga'" Cahiers d'études africaines 49(1973), 131. 
probably even before the manuscript was finalized. Hence we cannot assume that any of the views and interpretations expressed in Pilgrimage or "Adventures" are Battell's, nor do we have any clear idea of Battell's own assessments about the various African peoples he met.

\section{VIII}

While in Africa Battell did not keep a journal or a diary so that all his information stems from his reminiscences, some of which dealt with recent events of the last five years or so before 1613, while others went back one or even two decades. Once one realizes this, it is easy to find traces in his accounts of the process of memorization. That explains, at least in part, why there is so little about his first five years in Angola, compared to the later period. He structured his remembrances about Africa around his five attempts to escape, first on a Dutch ship, then from Massangano, then from the lord where had been left as a hostage, then from the Jaga, and finally and successfully by raft from Angola. He further seems to have placed all his other reminiscences in a narrative order by remembering them as occurring between such and such an escape, and he apparently had some trouble to place several of those that were not directly related to any of his escapes. As one would expect, some memories about moments of acute danger are among the most vivid-for instance, the negotiation of his surrender to a Portuguese captain (12-13), or his arrival in Cashil (23-25), He also easily remembered sequences of closely-linked events, such as his travels with the Jaga (24-28) or the main outline of the campaigns in Ilamba (13-16) and Kisama (36-37).

Furthermore, he retained, as most people do, some isolated but sharp mental images of places and people. His description of Benguella (16-18), of Ingombe (14-15), or of Jaga dress and ornaments (31-32) are typical. In contrast, his memories of repeated routines are poor and rather indistinct. .Examples of these include garrison life in Massangano and Cambambe, his commercial activities back and forth along the coast, and various episodes of his life as a hunter. And his memory failed him altogether when he was required to estimate durations of time, so that his chronology becomes a hopeless muddle, especially for his early years in Angola. Finally there are some signs of occasional confusion. Hence he still might delude himself, even though he was convinced that he remembered events and situations as they had happened,

Battell's reliability can be gauged by crosschecking his assertions with outside contemporary sources. That exercise shows him to be remarkably reliable on geographic places (rivers, places, mountains), on the succession, names, and activities of the governors in Angola after 1594, on trading 
routes, on commercial commodities, on prevailing social situations in Angola (e.g., vassality in the 1590s), and on Loango. Most of the Bantu words he cites can be identified despite their atrocious spelling and are either Kimbundu or Vili. Among the most impressive testimony to the reliability of his memory might be his recall of both the ethnic names Imbangala and Gindes, despite the fact that after 1600 all Europeans referred to them only as Jagas. ${ }^{23}$ Although the ethnonym Imbangala survives as a self-designation until today, Gindes did not. Apart from Battell it appears only once elsewhere. That was in a single text of 1591 that distinguishes "Guindas" from "Jaguas."24

So far everything seems to be quite satisfactory. Yet parts of Battell's accounts are unreliable. Like most other reminiscences, and indeed most writers, he cannot be trusted when it comes to numbers, especially any number based on an estimate rather than on detailed counting, and irrespective of its magnitude. $.^{25} 50,000$ African soldiers and 800 Portuguese (72) or 16,000 (33), 12,000 (85), 500 (19), "hundreds" of lords (21), 12 (33) Jaga, and even eight or nine slaves in a coffle $(70,75)$ are all equally suspect. The largest number of people that seems reliable in his account is 12 . They were the ones who escaped together from Massangano and the number is only believable because it is a count: he breaks it down (10-13) to 3+1 Gypsies, 7 Portuguese, and himself. Uncounted quantities such as the 4 tons (72) of ivory pre-1613 which became 3 tons after 1613 (25) or 20,000 elephants' hairs and tails (58) are not reliable either. As to estimates of distance, no number of miles or leagues is credible, mainly because no one had measured them, nor do we even know the standard length of the mile or of the league Battell used. ${ }^{26}$ Approximate distances expressed in days of travel hold up better, since they are a rough measure of distance, but unfortunately successive days or travel are repetitive experiences, and hence very difficult to remember correctly. So when we attempt to map such distances it soon becomes obvious that the estimates cannot be correct. Lastly in other instances a number is merely rhetorical, as for instance in "a man may travel twenty days in the shadow, without any sun or heat" (53).

${ }^{23}$ The older Pilgrimage has "Imbangolas" (84) and the later "Adventures" has "Gagas or Gindes" (19). Did the transcriber omit/delete Imbangala or did Battell no longer mention this?

${ }^{24}$ Brasio, Monumenta, 4:533, where Guindas are distinguished from Jaguas.In the 1680s these Guindas seem to have been remembered as Gingas. See José Mathias Delgado, ed. História das guerras Angolanas por António de Oliveira Cadornega. 1680 (2 vols.: Lisbon 1940), 1:52.

${ }^{25}$ See David Henige, Numbers from Nowhere (Norman, 1998), passim.

${ }^{26}$ Hence Ravenstein's footnotes (53) correcting Battell's "fifteen miles" and "two leagues" are an exercise in futility. 
From numbers it is a small step to the detailed chronology of his own past. Here too Battell is unreliable, especially for the early years in Angola. First we can only guess how he kept track of the passage of time, especially of months and years. Because the Christian week, the phases of the moon, and the round of the seasons are all repetitive, it is easy to lose track of an exact count, and Battell had no particular reason to keep such a count. So when it comes to time-reckoning, he hesitates himself, even for the most recent past. Thus he was in Loango two years and a half (77) or three years (41) and in Mayumba nine months (82) or one year (57). He was 16 months (83) among the Jaga, or at least $16+4$ months among them (26-27). ${ }^{27}$ One observes that his pre-1613 estimates are smaller than the post-1613 ones, which may betray a mnemonic tendency towards exaggeration. He also overestimates the duration of time he spent in boring routines, again something typical for remembrances. Thus the six years he supposedly spent in Massangano during the 1590 s seems far too long (10/13), as does the trading up and down the coast for governor Furtado de Mendonça for two and a half years in the earlier 1590s (9).

His estimate of over three years with the Ilamba campaign, still in the 1590s, comes closer to reality, and his two years in Cambambe (38) are only a little overestimated. As to durations of time spans in which he was not personally involved, some are correct, such as his report that Cafuxe defeated the Portuguese seven years earlier (27), while others are merely rhetorical, especially those with rounded numbers, such as (33) "[f]or it is more than fifty years since they came from Serra de Lion, which was their native country."

Considering that Battell had to remember so many names, events, and correct sequences of these, and whatever the excellence of his memory, one still expects him to be occasionally confused, and indeed sometimes that seems to be the case. For example, when he was with the Jaga he remembered (26) passing over high mountains south of the river Longa. These can only be the higher summits of the escarpment leading to the Benguela plateau. At the end of the same paragraph we again hear of "mighty high mountains and found it very cold" but these are now placed just south of the middle Cuanza, where there are no such mountains. Obviously he still refers to the peaks of the escarpment, but misplaces them. Or perhaps the transcriber misunderstood him here. Another instance concerns his claim to have traded for governor Furtado de Mendonça in the earlier 1590s. That

${ }^{27}$ Did Battell's numbers increase between his pre-1613 declarations and the ones after? For Loango, yes; for Mayumba, yes; for the Jaga, also yes, because pre 161316 months (in all), later 16 months (26)+4 months (27) makes 20 months . 
cannot be true because this governor had not yet arrived in Angola, and it probably does not apply to any earlier governor either because the duration of their administration was so short. Perhaps then these trips were for Mendonça, but are incorrectly placed in the sequence of events as related in "Adventures." But then perhaps he did make them in the early 1590s, but for other officials. ${ }^{28}$

Yet one should not be too quick to claim confusion as a solution for every discrepancy between Battell's narrative and other documents. Thus, remembering the campaign of 1603 in Kisama, Battell confused an earlier attack on Cafuxe by the Jaga with the Portuguese attacks of that year against the same chief, for he makes (27) chief Langere an ally of the Jaga, whereas in 1603 he was as an ally of the Portuguese..$^{29}$ In the same campaign he mentions as their main enemy "a mighty lord called Angoykayongo," whereas the written record specifies chief Cafuxe Cambare (37), whom Battell knew (27) as "Casoch." As to Angoykayongo, he appears in documents of 1606 and 1607, where he is identified as a Christian chief in Kisama named Agoacaiongo/ Angoacajongo, who was host to the Portuguese garrison there. ${ }^{30}$ So Battell apparently confused the chiefs against whom he fought. And yet, his memory is probably correct, because a contemporary document mentions that there were three battles in all during the campaign against Cafuxe and his allies. ${ }^{31}$ Before he went over to the Portuguese side, Angoykayongo might well have been one of those allies and the main enemy in the battle in which Battell participated.

Finally, Battell is rather too gullible. He includes two or three tall stories which he holds to be true, although he admits that he did not see them himself. The first is about a crocodile who swallowed a whole coffle of slaves. That must be true because he had seen crocodiles $(69-70,75)$. The second is about a great ape who kidnapped a boy "which lived a month with them," and that must also be true because he saw the same boy afterwards (55). The last of these is the story of the king who could not be seen drinking, which he simply presents as a known fact.

Yet on the whole Battell's information is quite straightforward. When he was an eyewitness he seems to be wholly reliable and where his accounts can be checked against outside contemporary documents they usually tally. Indeed his powers of recall are often surprisingly accurate. Nevertheless, he is sometimes confused. Apart from the cases cited, one suspects, for

\footnotetext{
${ }^{28}$ Between 1591 and 1594 there were four different governors and the situation in the colony was too dramatic to leave much time for official trading.

${ }^{29}$ Ralph Delgado, História de Angola (2d. ed.: Lobito 1961), 381, 390.

${ }^{30} 37 \mathrm{n} 3$; Brasio, Monumenta, 5:227, 391. Had he been a Portuguese ally in 1603 ?

${ }^{31}$ Ibid., 5:54: a Jesuit relation of 1603-04.
} 
instance, his descriptions of the outward appearance of persons or places. While these look quite convincing, some of the details in such descriptions might not relate to the persons or places described, but only to other similar ones. As for hearsay his information about the activities of the governors of Angola shows that he was often well-informed, but his tall tales also show that he was gullible. Still, this should not be overdone. To characterize Battell's information as "a lively set of mariner's tales" is a wild exaggeration. ${ }^{32}$

\section{IX}

Battell's story of the king who could not be seen drinking also appears in two other sources and thereby raises the issue of the independence of Battell's information from that of others. "Adventures" (45-46) tells us how the king of Loango killed his own twelve-year-old son because he had seen him drinking:

There was a boy of twelve years. Which was the king's son. This boy chanced to come unadvisedly when his father was drinking. Presently the king commandeth he should be well appareled and victuals prepared. So the youth did eat and drink. Afterward the king commandeth that he should be cut in quarters and carried around the city, with proclamation that he saw the king drink.

Now the Dutch trader Pieter van den Broecke tells the same story in a report dated to October 1612. A first version of this was written in Amsterdam after his return from Loango the month before, but the whole was amended again before publication as late as 1633. According to van den Broecke

During my time there I saw . . . that the king continually kept a young child, his own sister's son, at his side because he loved him every much. While playing, the child touched the king arm who was drinking, whereupon he immediatedly had the child killed, and its blood rubbed on his idols and charms. When I asked him why he

${ }^{32}$ Joseph Miller,"The Imbangala and the Chronology of Early Central African History" $J A H$ 13(1972), 563n55; idem., "Requiem," 123n6, is also a considerable exaggeration. Battell's account does not reveal "the influence of Portuguese from both Guinea and Kongo." Miller's only evidence for this is the use of tavale for a type of drum a word that could well be Senegambian. Moreover, the word might be the transcriber's and not Battell's choice. 
was so cruel to his own kin and to an innocent child, he replied that it was better the child than himself, for because (as the Devil had suggested to him) if he had not immediatedly had him[the child] put to death, than he himself would have to die. ${ }^{33}$

For his part he Swiss surgeon Samuel Brun, who had also been to Loango, tells the same story in his book published in 1624. This runs as follows:

If, however, someone inadvertently sees the king drink, he must die immediatedly. With this person's blood the king is anointed, as if thereby the king's honour, which would have been taken from him by those watching were redeemed. I myself saw how the king's own nine-year-old child got up from the ground, fell on the arm of its father, the king, perhaps out of love, and saw him drinking, whereupon Manna Magiischy said "this child must die." This indeed happened: in the father's presence, the child's brain was beaten in and the Manna Magiischy anointed the king's arm with the blood of the slain child. ${ }^{34}$

Obviously, the three travelers share the same story and their accounts cannot be independent from each other. Yet they did not directly copy from each other, since the three accounts differ in many details and contradict each other on small points. Moreover, it is not likely that either Brun or Purchas had access to van den Broecke's manuscript, which may be the earliest written account of the three, at least if this story was not added in 1633-34. While it is barely possible that Purchas might have seen Brun's Schiffarten a year or less before he published "Adventures," this sounds really farfetched, and in any case Battell's text is not a copy of Brun. ${ }^{35}$ So how did the three accounts come to share the same tale?

Both Pieter Van den Broecke and Samuel Brun claim to have witnessed the event itself. As they were both in Loango in 1612 this is possible and their accounts might still be independent from each other. But closer analy-

\footnotetext{
${ }^{33}$ Ratelband, Reizen naar West Afrika, 65, for the original. J.D. La Fleur ed. and trans. Pieter van den Broecke's Journal of Voyages to Cape Verde, Guinea and Angola, 16051612 (London 2000), 95-96, for a translation.

${ }^{34}$ Samuel Brun, Schiffarten. Welche er in etliche newe Länder ...gethan (Basel, 1624), 20; translated in Adam Jones, "Samuel Brun's Voyages of 1611-20" in German Sources for West African History 1599-1669 (Wiesbaden, 1983), 56-57, and nn 74-76, for references in later authors of 1625 and 1670.

${ }^{35}$ Van den Broecke was in Loango from April to September 1608, 30 January 1610 to April 1611, and February to June 1612. He wrote his description with this story in October 1612. Brun was there in 1612 .
} 
sis of the discrepancies between them show that Brun lied and Van den Broecke did not. The most telling flaws are Brun's confusion about the use of the blood and the medicine-man who saw it happen. To anoint the king's arm with blood makes no sense, while Van den Broecke's assertion that the royal charms were anointed with it does. And again, if no one could watch the king drink, the medicine man should not have been able to see what happened!

Other differences point to the same conclusion: an older child does not need to steady itself when standing up; it is not likely that any medicine man rather than the king would order the execution of a king's close relative; the affair is all the more significant if the child was a sister's son and hence heir to the throne rather than a son, and one might even doubt whether the child was killed by having its skull smashed rather than by stabbing. Still, Brun obviously heard the story in Loango, but he did not witness the events. Van den Broecke did, and that explains why his version is more detailed and its details are more plausible than either Brun's or Battell's.

For his part, Battell knew the story from hearsay, since he does not claim to have been an eyewitness. Did he hear it when both he and Van den Broecke were in Loango, in 1608, and then perhaps briefly in February 1610 , or did he hear it on board of the ship that brought him back? Probably neither. For in that case we would expect him to tell what was still a recent and sensational event to Purchas before 1613. But there is no such account, and it is highly unlikely that the Vicar of Eastwood would have missed such a dramatic tale to castigate superstitions in Loango and their barbaric consequences further. ${ }^{36}$ Moreover Battell's story is vaguer than the others and is more shaped as an etiological tale, warning what happens if one looks on a king drinking. In addition, the episodes of the last dinner before the execution, the quartering (a European custom), and the proclamation about town all have a suspicious folktale like ring to it. Such features point to a longer period of oral transmission than that of Brun's account, although the latter already exhibits a trace of the etiology. ${ }^{37}$

All this leads one to think that Battell did not hear the story in Loango, but learned about it only later, most likely from gossiping sailors or pilots in

\footnotetext{
${ }^{36}$ But Purchas' only comment about this in "Adventures": [980] was "tyrannicall Customs," much milder than such comments about the Jaga as "His dependance on the Devill," "Generation of Vipers," "His solemne sacrifice to the Devill," and "Butcherly rites" in "Adventures":[974, 976, 977].

${ }^{37}$ Brun, Schiffarten, 19-20. The event itself dates from 1611 or 1612 and could have been known in Amsterdam by early October of that year. It presumably occurred during a royal audience attended by van den Broecke. The possible dates are 9 April 1611, 15 February 1612, 22 March 1612 (least likely), or 18 June 1612.
} 
or near Leigh, and after his interviews with Purchas. ${ }^{38} \mathrm{He}$ then told it to his transcriber, who included it in "Adventures." This reconstruction implies then that "Adventures" includes at least one passage that is not based on information acquired by Battell before his return $c a$. 1610, but is of later date. Could there be more such passages? Probably not. Not only have none have been found, but it is not likely that there were others because there are no other tall stories in "Adventures" that are not also in Pilgrimage. In any case, while returning sailors from Loango and their gossip could easily reach the Thames, there was by then no such contact at all between the Thames estuary or Holland and Angola.

\section{$\mathbf{X}$}

From everything that has been said so far one may conclude, perhaps with reservations in the case of the murderous king of Loango, that the information attributed to Battell, even though written by Purchas or the transcriber, is quite reliable. Yet the Case of Sierra Leone shows it not to be completely so. Before meeting Battell Purchas seems to have accepted the views of Lopes/Pigafetta that the Jaga came from the Nile and originally formed but one people with the Galla and the Zimba (his Imbij). The most obvious trace of this mindset are the two passages in which interprets Imbangola as Imbi + Galla [772-773, 755 (marginal note)] or equates Gaga with Jaga. ${ }^{39}$ Less obvious, but just as revealing, is the inclusion of the crocodile story. It follows a sentence in which Purchas reminds the reader that overflowing rivers, crocodiles, and hippopotami are typical for the Nile and also found in the river Congo (Pilgrimage, 767). That betrays a mind that still links the Congo River to the Nile. But once he had heard Battell, he was converted to the latter's conviction that the Jaga came from Sierra Leone. In defense of this view he devotes a whole paragraph in Pilgrimage to a testimonial about Battell's unique reliability as a source:

Andrew Battell lived (by occasion of the Portugals treachery) with the lagges a longer time than ever any Christian or white man had done, namely sixteen months, and served them with their musket in the wars; neither could Lopez (saith he) have true intelligence

${ }^{38}$ La Fleur, Journal of Voyages, 96n2; S.P.L'Honoré Naber, ed., Toortse der Zee-Vaert door Dierick Ruiters (1623) and Samuel Brun's Schiffarten (1624) (s'Gravenhage, 1913), $15 \mathrm{n} 1$, who suggests - without much evidence-that Battell's text is probably derived from Brun.

${ }^{39}$ See the marginal notes to Hartwell's translation of Pigafetta in Ravenstein, Pilgrimage, 1005, 1025 and the entry in the Table The Giachas or Agagi. 
whence they came, for the Christians AT THAT TIME ${ }^{40}$ had but uncertain conjectures of them: neither AFTER had the Portugals any conversing, but by way of commerce; but he, being betrayed fled to them for his life and after, by stealth, escaped from them: the only European that ever lived in their camp. ${ }^{41}$

This is immediatedly followed in the next paragraph by:

He saith they are called lagges by the Portugals, by themselves Imbangolas (which name argues them to be of the Imbij and Galae before mentioned) and came from Sierra Liona. ${ }^{42}$

In paragraph four of the next page (83-84) he asserts it again:

Elembe, the great lagge, brought with him twelve thousand of these cruel monsters from Sierra Liona. . .

In 1625 a somewhat more detailed account in Adventures [974], (19-20) describes how a trading party that included Battell first met the Jaga.

WE asked them Who they were and then they told us that they were the Gagas, or Gindes; that cames from *Serra de Lion and passed through the Citie of Congo; and so traveled to the eastward of the great Citie of Angola, which is called Dongo. The great Gaga, which was their generall, came downe to the waters side to see us. For hee had never seene white men before. . . [Starred marginal note opposite Serra de Lion "Lopes was deceived in their originall"]

And further on [977], (33):

For it is more than fiftie years since they come from Serra de Lion, which was their native countrey. [marginal note "These Gagas came from Serra Leona" (Adventures)]

We learn from the first passage how Battell came to know about the origin of the Jaga. They told this to the Portuguese party with whom he traveled. But the chances are great that Battell did not witness this rather unlikely conversation (how could these Jaga know about Sierra Leone?), but was

\footnotetext{
${ }^{40}$ My small capitals.

${ }^{41}$ Ravenstein, Pilgrimage, 983-84.

${ }^{42}$ Ibid.
} 
told about it by his companions. Rather than relate exactly what the Jaga had said, they told Battell what they already knew from rumor and speculation long before meeting any Imbangala, namely that they had to be Jaga. The portion about Gagas or Gindes already occurred in Abreu de Brito's report of 1591 and was probably received wisdom in Luanda nearly a decade later. ${ }^{43}$ As to the Jaga having been in Congo and later east of Ndongo, that speculation derived from the false identification of Imbangala and Jaga and had probably also been made in Luanda.Yet the portion about Sierra Leone does not occur in Abreu de Brito, nor in any other document before Battell's report. Quite likely Battell also learned this from speculations rampant in Luanda.

For Purchas the notion of a Sierra Leone origin was a revelation that overturned the statements made by Lopes/Pigafetta about an origin on the Upper Nile. After all, Battell was the best authority on this question because he was the only one to have lived among the Jaga, and he stressed this in a marginal note in "Adventures" [975], referring to the translation by Hartwell of Pigafetta's book, a note that ended "[b]ut none could so well know as this Author, which lived so long with them." Moreover, in his own abbreviation of Hartwell that follows "Adventures" in Pilgrimes, Purchas makes the point twice more in marginal comments. First he writes: "[ $t]$ he Giaguas. Of these, see Andrew Battell which lived and warreth with them" and later: "[a]nd Battell sayth that the Iagges come from Sierra Leone." 44 Given these circumstances, it is not likely that Purchas himself interpolated the references to Sierra Leone in these texts. He clearly believed that the Imbangala had told Battell this.

Yet in the texts there is a tacit contradiction between 1613 "neither, after had the Portugals any conversing, but by way of commerce: ..." [772], (84), which sounds like an answer to another question asked by Purchas, but which juxtaposed to the preceding portion of the quote rather hints that Europeans in Africa did and could not know about the origins of the Imbangala. Nevertheless, in "Adventures" we hear that a Portuguese commercial party was told about this origin at their very first meeting with the Imbangala-even though the great Gaga had never seen white men before! Given Battell's overall reliability, it is clear that in 1613 it was Purchas, the author, who honestly concluded from the juxtaposition of two different statements

\footnotetext{
${ }^{43}$ Brasio, Monumenta 4:533. Guindas and Jaguas were kings neighboring the kingdom of Angola.

${ }^{44}$ A Report of the Kingdom of Congo, a Region of Affrica: Gathered by PHILIPPO PIGAFETTA, out of the Discourses of Master EDUARD LOPES a Portugall, translated out of the Italian into English by Master ABRAHAM HARTWELL and here abbreviated in Purchas His Pilgrimes (London, 1625), 2:1005, 1025.
} 
that Battell was the only credible witness to this affair and knew this directly from the Imbangala.

But in "Adventures" the mention of Sierra Leone is attributed to "we" and "us" that is to the Portuguese party, not to Battell himself. We saw that the statement most likely reflected current opinion at in Luanda in the later 1590 s, but we don't know who invented this origin. It obviously was applied first to the Jaga who overran the kingdom of Kongo and later extended to the Imbangala when they were equated with Jaga, probably before $1599 .{ }^{45}$ One suspects that the whole idea stems from the Jesuit establishment. ${ }^{46}$

But when all is said and done - and despite of the reliability of both Purchas and Battell - the account is still wrong. One error stems from the inference made by Purchas from the juxtaposition of Battell's answers to different questions, another one from his belief that the statement about Sierra Leone was made by the Imbangala to Battell himself and not to his Portuguese companions, while Battell's mistake was not to stress that his information was only hearsay.

All of the above becomes clear, however, only after a close reading and comparison of the texts of 1613 and 1625, which had not systematically been done. So how then have modern historians coped with the Sierra Leone statement? First none of them believed it, simply because Sierra Leone is too far away, but those who felt the need to explain the existence of the statement away did this in various ways. Ravenstein attributed the Sierra Leone statement to an interpolation by Purchas himself and saw a contradiction within the pre-1613 statements: no one could know their origins and the attribution of their origin to Sierra Leone. ${ }^{47}$ But he actually misread "at that time" and "after" in the text. The first refers to the time of Lopes not to the time of Battell, so there is no contradiction.

I suggested that "Sierra Leone"was only a translation of "mountains of the lion," perhaps somewhere in western Angola. That was also the explanation Joseph Miller adopted at first. ${ }^{48}$ This implies both that Battell made the

\footnotetext{
${ }^{45}$ See Jerónimo Castanho's reports to the king dated 5 September 1599, in Brasio, Мопиmenta, 4:599, 611, which might refer to an expedition in which Battell participated.

${ }^{46}$ Citations in Miller, "Requiem," $123 \mathrm{nn} 3$, 4, show that the link between the Mane in Sierra Leone and Congo had been laid already by 1594. But the Jesuit António Barreira in a letter between 1606 and 1610, is the first explicitly to derive the Jaga from the Mane rather than the reverse.

${ }^{47}$ Ravenstein, Strange Adventures, xii.

${ }^{48}$ Jan Vansina, "Foundation of the Kingdom of Kasanje, JAH 4(1963), 358n10; idem., Kingdoms of the Savanna (Madison,1966), 66; idem., "More on the Invasions of Kongo and Angola by the Jaga and the Lunda," JAH 7(1966), 421n3; Miller, "Imbangala," 56465.
} 
statement and that Purchas misunderstood him and turned Battell's words into Sierra Leone. David Birmingham simply ignored the Sierra Leone statement. ${ }^{49}$ Later, Miller arrived at about the same solution that is suggested by a close reading and comparison of both Battell texts. He documented the invention in Europe of the myth that all the famous nomadic and destructive peoples reported from sixteenth-century sub-Saharan Africa, including the Imbangala and Jaga stemmed from a single origin. He now argued that Battell, not Purchas, stated that the Imbangala came from Sierra Leone and added that Battell himself invented that link because he confused the Imbangala with the Jaga of Kongo..$^{50}$ The Sierra Leone origin was invented by "the Portuguese maritime establishment" (the rumor mill of Portuguese sailors in the Atlantic) and Battell knew about it because he had "traveled extensively on Portuguese trading vessels in the Atlantic." 51

A close reading of the 1625 text would have detected the "we" and the "us"and demonstrated that the connection between Imbangala and Jaga was made well before Battell's voyage, that the story of Sierra Leonian origin was then current in Luanda, and that one may surmise that the Jesuit establishment, rather than just sailors, were responsible for its creation.

\section{XI}

To judge by their references, all the twentieth-century historians who used Battell for their own research relied on the Ravenstein edition and never checked this with the original. This practice could easily have led them to commit major errors and yet, despite the defects of that edition, none of them did so. How is this to be explained? Primarily, I think, because the texts in Ravenstein are so faithful to the main texts of the originals that errors stemming from discrepancies between the edition and the originals are practically non-existent, so the authors could-and did-safely reproduce substantive information from the texts. In doing so they all seem to have ignored Ravenstein's arbitrary subdivisions and section headings. The main risk they ran was to ignore explicit or inherent contradictions between the texts of 1613 and 1625 and to appreciate the chronological difference

${ }^{49}$ David Birmingham, "The Date and Significance of the Imbangala Invasion of Angola," JAH 6(1965), 149; idem., Trade and Conflict in Angola (Oxford 1965), 66; 68-71. Like myself, he relied on Imbangala oral traditions recorded in 1851 rather than on Battell and proposed a putative origin of the Imbangala in the Rund kingdom.

${ }^{50}$ Miller, "Requiem" 121-23, 131. But in his Kings and Kingsmen: Early Mbundu States in Angola (Oxford, 1976), 177-78n6, he blames Purchas not Battell for identifying the Imbangala with the Jaga.

${ }^{51}$ Miller "Requiem," 123. 
between them. But such contradictions are rare, at least if one does not deal with any numbers. Practically all modern historians fell into the trap of accepting these numbers as reliable, but none of them made much of any numbers with the exception of the fifty-plus-year estimate for the migration of the Imbangala. Still, only a careful examination of the divergences between the texts mentioning Sierra Leone case could have led them to a satisfactory account for the origin of that piece of information. As we saw, only Miller arrived at this, albeit not by a close study of Battell's originals, but by the detour of European clichés accounting for the origins of marauding "hordes."

Secondly, major errors were also avoided because hitherto no author based any of her or his arguments on a very close reading of the texts. They used these in a rather passive, even desultory, fashion. For instance, Birmingham mentions the 1596 campaign in Bengo, but does not attempt to locate any of the chiefs or places mentioned. The reason for such an attitude was that the historiography of the 1960s and 1970s gave precedence to oral traditions and had a tendency to rely on texts merely as support for oral data. There is something of this even in Birmingham's work, even though his study is for the most part firmly based on textual evidence. For instance, when it came to the origin of the Jaga, Lunda oral traditions took precedence over Battell - an attitude both Miller and I shared at the time. ${ }^{52}$ On the other hand, Phyllis Martin used only Loango oral traditions to account for the origin of the kingdom. Otherwise she relied on Ravenstein's Battell, along with other contemporary travel accounts to build up a picture of Loango society in the early seventeenth century. ${ }^{53}$ In order to establish their reliability, they needed only to be cross-checked with each other because they overlapped with each other on most points, although they also seemed to be wholly independent of each other. So she did not feel the need to evaluate Battell's text very closely.

Because he focused on the Imbangala, Miller used Battell more than any other author. Athough he read a vast amount of archival and printed source material, all of this, Battell included, still took a backseat to the traditions he collected from modern Imbangala. ${ }^{54} \mathrm{He}$ used Battell's account in Ravenstein primarily to identify personal names similar to those mentioned by oral traditions. That approach led him to commit some errors, such as the preference for the name Calando (occurs once in "Adventures") rather than Calandola (occurs both in Pilgrimage and "Adventures"). Miller also com-

\footnotetext{
${ }^{52}$ See notes 42, 43 above and Miller Kinsmen.

${ }^{53}$ Phyllis Martin, External Trade of the Loango Coast (Oxford 1972), 5-41.

${ }^{54}$ Miller, Kings and Kinsmen, passim.
} 
pared various descriptive passages in Battell and several authors from the seventeenth century to recent Luba-Lunda ethnographies in order to demonstrate an Imbangala origin among the Lunda.

In doing this he did not question the reliability of Battell's descriptions, nor did he wonder to whom precisely they applied, and he lumped the information provided in the 1613 and 1625 texts together rather than to dwell on their discrepancies. That could also lead him into some errors. Thus he might attribute the funeral customs found both in Pilgrimage and "Adventures" to the Imbangala, whereas a comparison of both Battell texts (7374/34-35) makes it clear that they were Ambundu customs taken over by the Jaga. But Ravenstein's edition can hardly be faulted for mistakes of this sort, although it can be for the reverse chronological order in which it printed the texts and for his lack of attention in the introduction to this issue.

All in all then, and despite its defects and its outmoded annotation, the Ravenstein edition is still satisfactory for most purposes. But this does depend on the precise purpose of the user. For example, this edition would for be a disaster for any study of the overall image of Africa created by the "Adventures" in the minds of the English ecclesiastical and intellectual elites. This edition will also not be good enough for any conclusions that rest on the exact wording of Battell's testimony. For that purpose the originals must be consulted, if only to make certain of the original spelling of the relevant passages, in order to relate them to eventual marginal notes and to sharpen one's perception of the exact meanings these passages might have had by placing them in their seventeenth-century context and the atmosphere provided by the original books. Thus we end with a paradox: Battell's information is important enough and Ravenstein's edition is defective enough to warrant a new edition of the two texts, yet the Ravenstein edition is also good enough to serve the needs of most scholars. 